\title{
Studies on Preparation and Preservation of Value Added- Herbal Product of Anonla Squash (Emblica officinales G.) cv. NA-7
}

\author{
Supriya Singh* and Saket Mishra
}

Department of Horticulture, Sam Higginbottom University of Agriculture Technology and

Sciences, Allahabad (U.P.) 211007, India

*Corresponding author

\section{A B S T R A C T}

\begin{tabular}{|l|}
\hline Ke y w o r d s \\
Stevia, Browning \\
colour, Squash, \\
Lemongrass, \\
Ascorbic acid, \\
Cardamom. \\
\hline Article Info \\
\hline $\begin{array}{l}\text { Accepted: } \\
\text { 23 June } 2017 \\
\text { Available Online: } \\
\text { 10 July } 2017\end{array}$ \\
\hline
\end{tabular}

A study was carried out to detect the effect of different levels of herbals and quality attributes in anola beverages during storage in Department of Horticulture SHUATS, Allahabad in the year 2016-2017. The experiment was laid out in Complete Randomized Design (CRD) with three replication and nine treatments. The concept of formulation of anola beverages is with three levels of each stevia, cardamom and lemongrass as additives. All the herbal treatments were found better in respect of TSS, Ascorbic acid, $\mathrm{pH}$, Browning Expect acidity content. Results showed that maximum TSS (47.89 ${ }^{0}$ Brix), and $\mathrm{pH}(2.27)$ were observed in $\mathrm{T}_{9}$, ascorbic acid $(23.79 \%)$ $\mathrm{T}_{6}$, Acidity (1.15\%) in $\mathrm{T}_{0}$ and browning (OD) (0.308) in $\mathrm{T}_{3}$ on the barring storages period (5months).

\section{Introduction}

The Indian gooseberry or aonla belongs to family Euphorbiaceae and botanical Name Emblica officinales G. and is indigenous to India. The present area under aonla cultivation in India is about 55,000 hectares and Uttar Pradesh is the major growing state in the country. The fresh fruits of aonla are very rich source of Nutrient-Ascorbic acid (454.40mg/100g), calcium (14.91mg/100g), Iron $(0.62 \mathrm{mg} / 100 \mathrm{~g})$ and phosphorus $(11.81 \mathrm{mg} / 100 \mathrm{~g})$ Other-source of total sugar $(7.53 \mathrm{mg} / 100 \mathrm{~g})$, and has great potential for processing (Dachiya and Dhawan, 2001). The edible fruits tissue of Aonla contains about 3 times as much protein and 160 times as much vitamin "C" as apple (Barthakur and Arnold
1991). Aonla fruits are widely used in Unani and Ayurvedic system of the medicine Aonla fruits is the main ingredient in Chavanprash and is one of the three ingredients in Triphla used in the treatment of head cake, constipation liver and hence is preferred in the form of preserves, dried aonla, jam, juice, pickle and toffees and fruit bar. It is probably the most important natural source of vitamin $\mathrm{C}$, which is easily absorbed by the digestive system (Singh and Kumar, 2000).

Anola fruits are sour and astringent in taste. Anola qualities are light and dry the post digestive effect is sweet its energy is cooling. Anola is used to revitalizing potency and the 
digestive system, treat constipation, reduce fever, purify the blood, reduce cough, benefit eyes, and stimulate hair growth.

Indian cardamom is used known in two main varieties: Malabar cardamom and Mysore Cardamom. The Mysore variety contains higher levels of cineol and limonene and hence is more aromatic. Cardamom is often included in Indian sweet dishes and drinks. Other uses are; in pickles, especially pickled herring; in punches and mulled wines; occasionally with meat, poultry and shellfish. Cardamom is used as a spice and as an ingredient in traditional medicine in systems of the traditional Chinese medicine in China, Japan, Korea and used in Ayurveda in India (Alvarez, 2008). Green cardamom powder is used as a spice for sweet dishes as well as traditional flavoring in coffee and tea.

Stevia (Stevia rebaudiana) also known as "Honey plant" or "calorie free plant" is a perennial herb belonging to the family Asteraceae. Originated from Paraguay the crop is widely distributed in USA Brazil, Japan, Korea and Taiwan. It is rich source of natural sweeter and alternative to cane sugar.

The leaves have been traditionally used for hundreds of year in both Brazil and Paraguay to sweeten local teas and medicine. Mainly use stevia Diabetes, Weight control, pancreatic cancer, Blood pressure (Shadap and Pariari, 2015).

Lemon grass (Cymbopogon flexusos) a Perennial grass belongs to the family Graminae. It is native to India and found growing wild in tropical and subtropical parts. The plant produces aromatic oil with a characteristic lemon like odor (due to the presences of citral). The oil is mostly used for scenting of soaps, cosmetic and disinfectant. Citral is used as starting compounds for manufacturing ionone's and vitamin A (Shadap and Pariari, 2015).

\section{Materials and Methods}

Fully ripened, mature, fresh and sound aonla fruit were purchased from the orchard of the Department of Horticulture, Sam Higginbottom University Agriculture Technology and Sciences, Allahabad and the materials such as sodium benzoate was sourced from the P.G. laboratory, Department of Horticulture, SHUATS, Allahabad (Fig. 2). Commercial grade white crystalline cane sugar, big green cardamom and big size dried Lemongrass and stevia were also purchased from local market. After pricking fruits were dipped in $2 \%$ salt solution for $24 \mathrm{~h}$., then washed with clean water and again dipped in $2 \%$ alum solution for $24 \mathrm{~h}$., further washed with clean water and then blanched in boiling water for 10 minutes. Anola fruits were washed in tap water and then were peeled and divided into halves. Fruit juice was extracted in a citrus juice extractor. After juice extraction the juices were kept for 24 hours in refrigerator $\left(4-2^{\circ} \mathrm{C}\right)$ for sedimentation (Table $1)$.

Then the clear juice was siphoned off and strained through muslin cloth. Aonla raw juice was heated at $96^{\circ} \mathrm{C}$ for two minute to inactivate enzymes. All prepared juices, sodium benzoate and sugar were blended in high speed blender at $8000 \mathrm{rpm}$ for $2 \mathrm{~min}$. Nine treatments combination were formulated with sugar and herbs (cardamom, lemongrass and stevie). Treated RTS samples are evaluated at 0,30 , and 60 days (30 days intervals) at 5 months storage for physiochemical analysis and sensory evaluation.

\section{Results and Discussion}

The present investigation was conducted in year 2016-2017, at the Post harvest lab, Department of Horticulture, Sam Higginbottom University of Agriculture, Technology and Sciences, Allahabad. 


\section{Total soluble solids (\%)}

The average maximum total solids content (47.89\%) was found in $\mathrm{T}_{9}$, followed by $\mathrm{T}_{8}$ $(47.82 \%)$ whereas the minimum $(46.82 \%)$ was noticed in $\mathrm{T}_{0}$ in 5 month of storage.

\section{Ascorbic acid (\%)}

The average maximum ascorbic acid content (23.79\%) was found in $\mathrm{T}_{6}$, followed by $\mathrm{T}_{8}$ $(23.10 \%)$ whereas the minimum $(21.41 \%)$ was noticed in $\mathrm{T}_{0}$. in 5 month of storage.

Table.1 Combination of herbs used in aonla squash treatments

\begin{tabular}{|c|l|}
\hline Notation & Treatment combination \\
\hline $\mathrm{T}_{0}$ & Control \\
\hline $\mathrm{T}_{1}$ & $($ Stevia 0.5\%)+Anola juice 25\%+TSS 40\% \\
\hline $\mathrm{T}_{2}$ & $($ Stevia1.0\%)+Anola juice 25\%+TSS 40\% \\
\hline $\mathrm{T}_{3}$ & $($ Stevia 1.5\%)+Anola juice25\%+ TSS 40\% \\
\hline $\mathrm{T}_{4}$ & $($ Cardamon 0.5\%) +Anola juice 25\%+ TSS 40\% \\
\hline $\mathrm{T}_{5}$ & $($ Cardamon 1.0\%)+Anola juice 25\% + TSS 40\% \\
\hline $\mathrm{T}_{6}$ & $($ Cardamon 1.5\%)+Anola juice 25\% +TSS 40\% \\
\hline $\mathrm{T}_{7}$ & (Lemongrass 0.5\%)+ Anola juice25\% + TSS 40\% \\
\hline $\mathrm{T}_{8}$ & $($ Lemongrass 1.0\%)+ Anola juice 25\% +TSS 40\% \\
\hline $\mathrm{T}_{9}$ & $($ Lemon grass 1.5\%)+ Anola juice 25\% + TSS 40\% \\
\hline
\end{tabular}

Table.2 Effect of different treatments chemical analysis herbal product of aonla squash during 5 month storage period

\begin{tabular}{|c|c|c|c|c|c|}
\hline Treatments & \multicolumn{1}{|c|}{ TSS ( $\mathbf{(}^{\mathbf{0} B r i x)}$} & $\begin{array}{l}\text { Ascorbic } \\
\text { acid (\%) }\end{array}$ & Acidity (\%) & Ph & $\begin{array}{l}\text { Browning } \\
\text { (OD) }\end{array}$ \\
\hline $\mathbf{T}_{\mathbf{0}}$ & 46.82 & 21.41 & $\mathbf{1 . 1 5}$ & 2.06 & 0.188 \\
\hline $\mathbf{T}_{\mathbf{1}}$ & 47.06 & 21.71 & 1.14 & 2.10 & 0.248 \\
\hline $\mathbf{T}_{\mathbf{2}}$ & 47.23 & 21.49 & 1.14 & 2.10 & 0.288 \\
\hline $\mathbf{T}_{\mathbf{3}}$ & 47.36 & 22.15 & 1.13 & 2.20 & $\mathbf{0 . 3 0 8}$ \\
\hline $\mathbf{T}_{\mathbf{4}}$ & 47.28 & 23.46 & 1.13 & 2.16 & 0.218 \\
\hline $\mathbf{T}_{\mathbf{5}}$ & 47.45 & 23.58 & 1.12 & 2.20 & 0.228 \\
\hline $\mathbf{T}_{\mathbf{6}}$ & 47.65 & $\mathbf{2 3 . 7 9}$ & 1.12 & 2.22 & 0.248 \\
\hline $\mathbf{T}_{\mathbf{7}}$ & 47.71 & 22.70 & 1.12 & 2.23 & 0.108 \\
\hline $\mathbf{T}_{\mathbf{8}}$ & 47.82 & 23.10 & 1.09 & 2.23 & 0.128 \\
\hline $\mathbf{T}_{\mathbf{9}}$ & $\mathbf{4 7 . 8 9}$ & 23.29 & 1.11 & $\mathbf{2 . 2 7}$ & 0.158 \\
\hline Mean & 47.43 & 22.67 & 1.13 & 2.27 & 0.212 \\
\hline F- test & $\mathrm{S}$ & $\mathrm{S}$ & $\mathrm{S}$ & $\mathrm{S}$ & $\mathrm{S}$ \\
\hline S.Ed. & 0.100 & 0.275 & 0.0124 & 0.002 & 0.005 \\
\hline C.D.at 5\% & 0.213 & 0.583 & 0.0263 & 0.005 & 0.011 \\
\hline
\end{tabular}


Fig.1 Effect of different treatments chemical analysis herbal product of aonla squash during different storage period

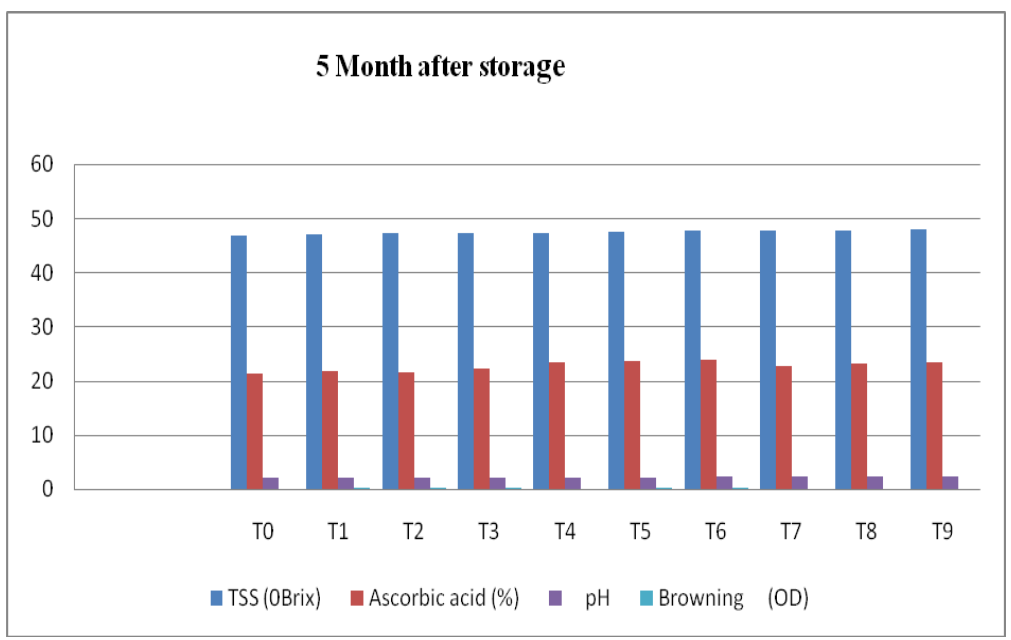

Fig.2 Anonla squash (Emblica officinales G.)

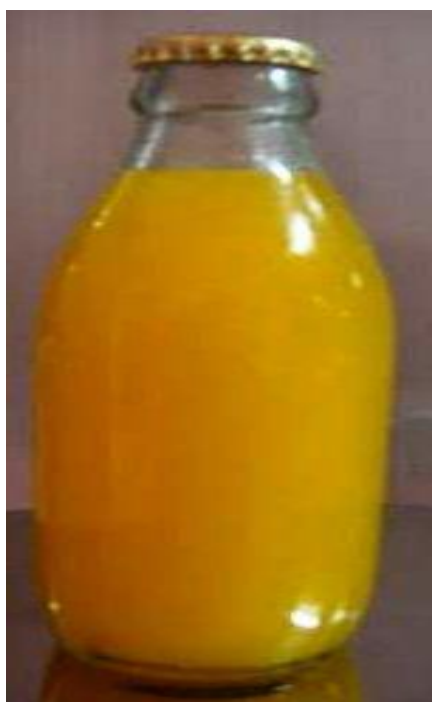

Acidity (\%)

The average maximum Acidity content $(1.15 \%)$ was found in $T_{0}$, followed by $T_{1}$ $(1.14 \%)$ whereas the minimum $(1.11 \%)$ was noticed in $\mathrm{T}_{9}$. in 5 month of storage.

\section{pH}

The average maximum $\mathrm{pH}$ content (2.27) was found in $\mathrm{T}_{9}$, followed by $\mathrm{T}_{8}(2.23)$ whereas the minimum (2.06) was noticed in $\mathrm{T}_{0}$. In 5 month of storage.

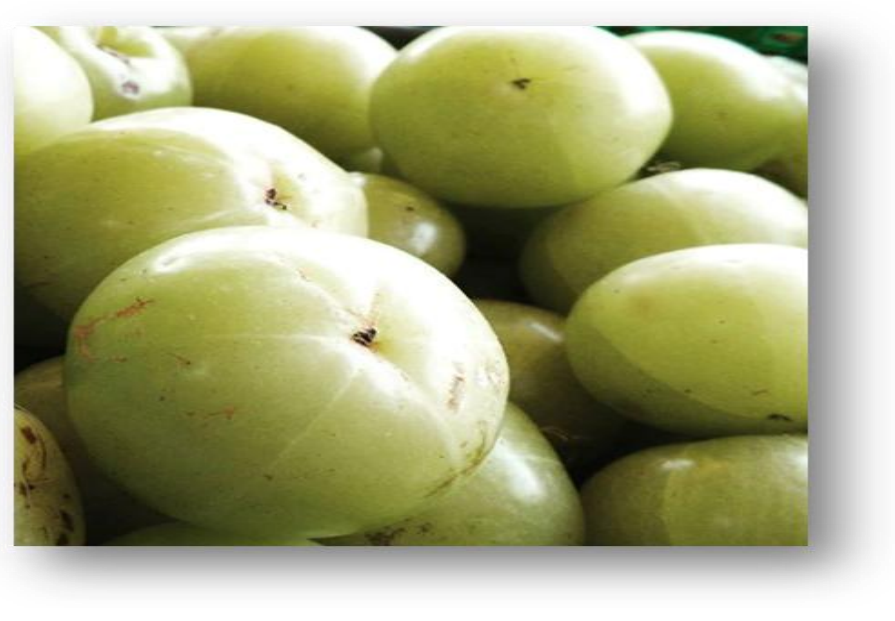

\section{Browning (OD)}

The average maximum browning content (0.308) was found in $T_{3}$, followed by $T_{2}$ (0.288) whereas the minimum (0.108) was noticed in $\mathrm{T}_{7}$ in 5 month of storage (Table 2 and Fig. 1).

\section{References}

Alvarez L. (2008). Cardamom prices leads to a re-emergence of the green gold.

Archana P., Laxman K and Praveen J. (2013) 
Standardization of recipes for tamarind paste and squash. J. Hortl. Sci. Vol. 8(2):282-287.

Barthkur, N.N. and Arnold (1991). Chemical analysis of anola (Emblica officinalis $G$.) and its potential as an fd. Source scienta 47 (1-2, 99-105)

Balaji V., and Prasad. V.M. (2014).Studies on Value added Kinnow-Aonla blended ready to serve beverage. J. Food Process Tech. (vol. 5, Issue 1)

Choudhary M.L., Verma I.M., Singh J., Chandra A. and Godara S.L (September 2013) Studies on biochemical changes in aonla (Emblica officinalisG.) squash under storage condition Vol. 45, No. 2

Dobhal, P. (2000). Studies on preparation and preservation of phalsa (Grewias ubinaequalis L.) beverageM.sc N.D. University Of Agriculture And Technology, Faizabaad (UP).

Dhiya, S.P. and Dhawan, S.S. (2001a) PhysicoChemical characteristics of anola (Embilica officinalis) Chakaiya, Ind. Fd. Pack., 55 (6). 133.

Dahiya, S.P. and Dhawan, S. S. (2001b) physicchemical characteristics of anola chakaria, Ind Fd Pack., 55 (6): pp. 444452.

Joseph J.andShukla S. (2015) Preparation and Quality Evaluation of Mixed Fruit Squash, Vol.3, No.3

Jaiswal R., Singh G and Singh A.K. (2008). Evaluation of Anola (Emblica Officinalis G.) cultivar for squash making. Prog. Agric. 8 (1): 29-31

Pandey, A.K. (2004). Study about the storage stability of guava beverages. Progressive Horticulture 36(1): 142-145

Pathak S. (1998). Post-harvest technology of anola (Emblica officinalis G.) fruit Ph.D thesis N.D. University of agriculture and Technology, Faizabad.

Pathak, R.K. and Singh, I.S. (1998).Anola production and Post-harvest technology, 30-31.

Sethi, V. (1980).Studies on preparation and storage of some semi dry preserve (Murabba) Ph.D thesis I.A.R.I New Delhi.

Singh, S (2002) Studies on preparation of rangpur lime (Citrus LimoniaOsbeck) beverage M.Sc. thesis N.D. University of Agriculture and Technology, Faizabaad (UP).

Singh, S. (2002a) Studies on preparation and preservation of Rangpur lime (Citrus limonia Osbeck) beverages M.Sc. Thesis N.D. University of Agriculture and Technology, Faizabad (U.P.)

Singh, S. (2002b) Studies on preparation and preservation of ginger (Ginger officinalis L.,) beverages M.Sc. Thesis N.D. University of Agriculture and Technology, Faizabad (U.P.)

Singh, Om and Singh, Richa (2014).Development and evaluation of aonla blended nectar drink from different fruits using stevia for low calorie. Plant Archives Vol. 14 No.1, pp. 115-119.

Sangita S. and Shilpa (2015) Assessment of Storage Stability of Tinospor acordifolia (Giloy) Based Squash International Journal of innovate research development, Vol 4: Issue 2.

Shadap A. and Pariari A. (2015) Glimpse of spices, Plantation crops, Medicinal and Aromatic plants AGRO India publication.

Tressler, D.K. and Joslyn, M.A. (1971).Fruit and vegetable juice processing technology, AVI Pub Co. Ind.

\section{How to cite this article:}

Supriya Singh and Saket Mishra. 2017. Studies on Preparation and Preservation of Value AddedHerbal Product of Anonla Squash (Emblica officinales G.) cv. NA-7. Int.J.Curr.Microbiol.App.Sci. 6(7): 2200-2204. doi: https://doi.org/10.20546/ijcmas.2017.607.319 